\title{
The Impact of Labor Demand on Time to the Doctorate*
}

\author{
Jeffrey A. Groen ${ }^{\dagger}$ \\ U.S. Bureau of Labor Statistics \\ CHERI Working Paper 146 \\ First Version: January 11, $2012^{\oplus}$ \\ This Version: June 25, 2014 \\ Forthcoming, Education Finance and Policy
}

\begin{abstract}
The goal of this paper is to estimate the impact of labor demand for new $\mathrm{PhD}$ recipients on time to the doctorate. Empirical investigation of this relationship in previous research was hampered by the difficulty of measuring labor demand. I construct a measure of labor demand based on the annual number of job listings from 1975 to 2005 in seven fields in the humanities and social sciences. My empirical strategy relates variation over time in the number of job listings within a field to the timing of completion using student-level data on all doctorates awarded in these fields by U.S. universities. Estimates indicate that the number of job listings is not correlated with the probability of completion and expected time to degree. This finding implies that cyclical variation in labor demand is not responsible for changes in time to degree within fields.
\end{abstract}

JEL classification: I23; J22; J23; J44.

Keywords: Time to degree; Labor demand; Doctoral students; Academic labor market.

\footnotetext{
* I am grateful to Sharon Brucker, Matt Dey, Ron Ehrenberg, John Ham, Anne Polivka, and Stephanie Cellini for useful comments and helpful discussions. This paper has benefitted from comments of two anonymous referees and seminar participants at the Bureau of Labor Statistics, the National Bureau of Economic Research Education Program meeting, the Society of Government Economists conference, the American Economic Association meetings, and the Population Association of America meetings. I thank the National Science Foundation (NSF) for providing access to restricted-use data from the Survey of Earned Doctorates (however, the use of NSF data does not imply NSF endorsement of the research, research methods, or conclusions contained in this paper). I also thank Mike Rizzo for sharing data on state appropriations and college expenditures and Mark Long for sharing data on admissions selectivity. The views expressed in this paper are solely those of the author and do not reflect the views of the Bureau of Labor Statistics.

† E-mail: Groen.Jeffrey@bls.gov. Address: 2 Massachusetts Avenue NE, Room 4945, Washington, DC 20212.

${ }^{\oplus}$ When this paper was first released as a CHERI Working Paper, it was titled “Time to the Doctorate and Labor Demand for New PhD Recipients.”
} 


\section{Introduction}

Unlike training for professional degrees such as an MBA, training for a $\mathrm{PhD}$ takes an amount of time that varies widely across students within a given field. In the humanities, for instance, some students complete the $\mathrm{PhD}$ in as little as 5 or 6 years while others take 11 or 12 years (Ehrenberg et al. 2009). The goal of this paper is to estimate the impact of labor demand for new $\mathrm{PhD}$ recipients on time to the doctorate. Within a field the demand for new $\mathrm{PhD}$ recipients varies from year to year because the number of employers hiring and the number of positions available depend on macroeconomic conditions, state budgets, and university priorities (Oyer 2006). As a result, two students from the same department seeking jobs in consecutive years may face quite different sets of opportunities.

The absence of a time limit in doctoral education allows doctoral students the opportunity to adjust their completion decisions to match the labor market, slowing down when the market is weak and speeding up when the market is strong. If students were free to choose when to go on the job market and had accurate information about labor demand, they may be able to improve their job prospects by adjusting their completion timing. However, faculty advisors may push students to complete their degrees without regard to labor-market conditions in order to avoid a large number of almost-finished $\mathrm{PhD}$ students in their department. It may also be difficult for students to obtain an accurate assessment of current labor demand without engaging in a timeconsuming job search.

Universities have become more concerned in recent years about long time to degree (TTD) and high attrition rates in PhD programs (Ehrenberg et al. 2009; Council of Graduate Schools 2010; Ostriker et al. 2010). The extent to which time to degree is influenced by labor demand is relevant for institutional policies. Some institutions set limits on the number of years 
that $\mathrm{PhD}$ students may receive institutional funding (Ehrenberg et al. 2009). If labor demand affects TTD, institutions with such policies may decide to increase the limits during periods when labor demand is weak. Determining the effect of labor demand on TTD is also important so that this effect can be compared to the effects on TTD of other factors.

Prior research on time to the doctorate has identified a range of potential factors in TTD. Tuckman, Coyle, and Bae (1990), based on a review of the literature, outlined a conceptual model with five sets of factors: family characteristics, student characteristics, tuition and financial support, institutional environment and program characteristics, and market forces including labor demand for new PhD recipients. Empirical studies of TTD in doctoral education have addressed the role of the first four sets of factors, but they have not adequately addressed the role of labor demand. ${ }^{1}$ The primary reason for this is the difficulty of measuring labor demand. $^{2}$ Given this difficulty, some studies (e.g., Abedi and Benkin 1987) did not even attempt to control for changing market opportunities for doctorates in different fields over time. Other studies (e.g., Ehrenberg and Mavros 1995; Stephan and Ma 2005) used proxies, but these proxies do not adequately isolate the demand for new doctorate recipients.

The primary contribution of this paper is to provide a direct measure of labor demand and to use it to estimate the impact of labor demand on TTD. The measure of labor demand is constructed from counts of job vacancies advertised with professional associations. This paper demonstrates that vacancy-based statistics can be constructed by field over a long time period.

\footnotetext{
${ }^{1}$ Prior empirical studies of TTD include Abedi and Benkin (1987), Tuckman, Coyle, and Bae (1990), Bowen and Rudenstine (1992), Ehrenberg and Mavros (1995), Espenshade and Rodriguez (1997), Siegfried and Stock (2001), Ehrenberg et al. (2007), and Groen et al. (2008).

2 Stephan and Ma (2005, p. 72) remarked: "Measures of the strength of the job market are notoriously difficult to construct.”
} 
Furthermore, the paper provides evidence that the annual number of job listings in a field is a credible measure of labor demand for new $\mathrm{PhD}$ recipients.

The remainder of the paper proceeds as follows. The next section presents a conceptual framework of student progress towards the $\mathrm{PhD}$ and discusses the potential role of variation over time in labor demand. Section 3 describes the data used in the empirical analysis: comprehensive student-level data and annual counts of job listings by field from 1975 to 2005 for seven fields in the humanities and social sciences. Section 4 presents the empirical approach that is used to estimate the impact of labor demand on TTD. The empirical estimates are presented in Section 5. Section 6 discusses the main findings and some implications.

\section{Conceptual Framework}

To motivate the empirical analysis, this section outlines a conceptual framework for understanding how labor demand for new PhDs may affect student progress towards the $\mathrm{PhD}$. Prior to discussing the problem at the micro level, it is useful to situate the problem at the macro level. Consider the academic labor market in the United States in a particular field (such as history or economics) in terms of a standard model of supply and demand. The demand for labor in the field changes over time due to changes in state appropriations, the size of college-going cohorts, the demand for undergraduate courses in the field, the performance of university endowments, and other factors (Oyer 2006).

When the demand curve shifts out, the market equilibrium moves along the (short-run) supply curve, and both wages and the quantity of labor increase. The amount that quantity increases depends on the elasticity of supply. One component of the supply elasticity is the responsiveness of the production of new $\mathrm{PhDs}$ to a change in demand. Given the typical length of time from entering a doctoral program to earning a $\mathrm{PhD}$, it is not feasible for new doctoral 
students to generate an increase in the number of doctorate recipients in the short run in response to an increase in demand.

However, students who are already enrolled in PhD programs and working on their dissertations could speed up their progress in order to move more quickly into the labor market. At the market level, then, this paper addresses whether the number of PhDs produced in a field responds to short-run changes in demand in the academic labor market via completion behavior of existing students. The overall elasticity of supply is also affected by the responses of other potential suppliers, including doctorate holders who are not currently working, those working in the non-academic sector, and those working in other countries (see Ehrenberg 1992).

At the micro level, the speed at which a student progresses towards the $\mathrm{PhD}$ might be influenced by a variety of factors. Some of the factors relate to the student's institution or department, such as funding, course requirements, and advising. Other factors are largely in students’ control, including the effort and amount of time they devote to their studies and research as compared to outside employment, home production, and leisure activity.

Students can be expected to influence their degree progress by balancing the costs and benefits of additional time spent working on their research. Chief among the benefits is the quality of the dissertation; in turn, a better dissertation may lead to a better job. Other benefits that are productive for students include access to library resources at their universities and access to advisors, classmates, and others on campus. Remaining a student rather than finishing the PhD also confers several consumption benefits, including on-campus student housing and subsidized health insurance.

The costs of longer TTD include direct financial costs (i.e., tuition and related expenses) as well as the opportunity cost of remaining a student. The opportunity cost reflects the greater 
expected wage from having a $\mathrm{PhD}$ compared to not having a $\mathrm{PhD} .{ }^{3}$ The financial payoff to obtaining a $\mathrm{PhD}$ in a field is a function of starting salaries for academic positions, the number of academic positions available, and the availability of nonacademic alternatives. Beyond opportunity costs, longer TTD can be costly by providing a negative signal of individual ability or effort. Even in the humanities (a set of fields with long average TTD), degree times longer than 8 years are associated with worse job outcomes (Ehrenberg et al. 2009).

If labor demand for new PhDs influences the speed of student progress, the effect would operate primarily through opportunity costs. An increase in labor demand would raise the financial payoff to obtaining a $\mathrm{PhD}$, thereby increasing the opportunity cost of remaining a student. This cost can be considered an increasing function of the probability of getting an academic job, the starting salary of that job, and the status of that job (e.g., tenure status and type of institution). The increased opportunity cost would be expected to increase the speed of student progress and lower TTD. I expect that any effect of labor demand on TTD would operate primarily at the dissertation stage of doctoral programs rather than at the coursework stage.

The reasoning above assumes that students have control over their completion date. However, students may not be completely free to adjust their completion timing. Even if postponing completion in the face of weak labor demand may be beneficial to individual students, their advisors may push them to complete their degrees when they are ready (i.e., without regard to labor demand) in order to avoid a large number of almost-finished $\mathrm{PhD}$ students in their department. If departments were to postpone the completion of some students

\footnotetext{
${ }^{3}$ The relationship between opportunity costs and PhD TTD was emphasized in general terms by Breneman (1976) and Tuckman et al. (1990). The role of opportunity costs in influencing undergraduate TTD was considered by Messer and Wolter (2010).
} 
who are ready to graduate, that would create more competition in the labor market in subsequent years for students who become ready to graduate. As a result, even though student placement is important for a department's reputation, allowing students to adjust their completion timing in response to labor-demand shifts might not produce an increase in the average quality of student placements.

Informational issues may also limit the impact of labor demand on TTD. Even though job listings are relatively easy for students to access, what the listings reveal about labor demand may not be immediately clear to students. Obtaining an accurate assessment of current labor demand — in a field generally and in a student's specific area of concentration—may require a substantial time commitment in order to apply for positions, arrange for interviews and presentations, and learn the specific details of the position associated with each listing. As a result, students might be unwilling to make such a time commitment if they are not close to finishing their dissertations. When students commit the time to a job search and find limited opportunities, they may take the best available offer rather than wait until the next hiring cycle.

\section{Data}

\subsection{Student Data}

The empirical analysis in the paper is based on microdata on students who received doctorates from 1975 to 2008. These data come from the Survey of Earned Doctorates (SED), a census of research doctorates from U.S. universities. The survey, which is sponsored by the National Science Foundation and five other U.S. government agencies, is administered to doctorate recipients once they finish their degree requirements. The response rate is very high (usually over 90 percent annually), and basic information for nonrespondents (field of study, 
degree date, doctorate institution, and gender) is obtained from their degree-granting institutions and from public records (Hoffer et al. 2006).

The measure of TTD used in this analysis is the number of years from graduate entry to the $\mathrm{PhD}$, where graduate entry is defined as entrance into the first institution after the first baccalaureate was earned. Graduate entry would be prior to entry into the program that awarded the $\mathrm{PhD}$ if a student completed a stand-alone master's degree before entering the $\mathrm{PhD}$ program. Although this measure of TTD doesn't always capture the beginning of PhD study, it does capture the end of $\mathrm{PhD}$ study, which is the critical endpoint for the empirical approach taken in this study of completion timing. This measure of TTD is the best one available in the SED for the time period of the study. An alternative measure of TTD, starting from entry into a PhD program, is conceptually more appropriate but is available in the SED only for individuals who completed the $\mathrm{PhD}$ in 1993 or later.

In addition to TTD, several other variables are created from the student responses to the SED. Financial aid received by students is summarized by the primary source of support during graduate school. Information on each student's institution, field, and year of graduate entry are used to assign a rank and size of the doctoral program, based on the 1981 and 1993 National Research Council assessments (see the Appendix for details). Also available from the SED are standard demographic variables (age, gender, and race/ethnicity) along with citizenship. Unfortunately, the SED data do not include a measure of student ability such as test scores. As a proxy for student ability, I use admissions selectivity of each student's bachelor's institution in one part of the analysis.

The SED sample used in this paper covers seven fields in the humanities and social sciences: anthropology, classics, economics, English, history, philosophy, and political science. 
These fields were chosen because the time-series data on job listings were available and because the fields are in related disciplines. The fields represent 51.8 percent of all doctorates awarded in the humanities and social sciences from 1975 to 2008. Table 1 summarizes the personal characteristics of doctorate recipients in these fields. Table 2 summarizes the distribution of TTD by field. Median TTD is highest in anthropology and lowest in economics. In each field the mean TTD exceeds the median, reflecting the long right tail of the distribution. Within fields there is substantial variation in TTD across students, with a difference of 5 years between the 25th and 75th percentiles being typical.

\subsection{Job Listings}

I measure labor demand for new $\mathrm{PhD}$ recipients using the annual number of job listings in each field. I collected these data from a professional association for each of the seven fields (see the Appendix for details). Each association serves a vital organizing role in the labor market for doctorate recipients in a discipline by publishing listings (advertisements) of job vacancies. Field-specific job listings are conceptually a better measure of the demand for labor in a particular field than general measures such as the unemployment rate and the help-wanted index. ${ }^{4}$ In addition, job listings are a more direct measure of labor demand than the proxy variables used in the literature on TTD and the academic labor market. For example, Ehrenberg and Mavros (1995) used the mean starting salary for new assistant professors in a field and Stephan and Ma (2005) used the percentage change in total current-fund revenue of public institutions.

\footnotetext{
${ }^{4}$ The unemployment rate has been used as a measure of labor demand in studies of cohort effects for college graduates (Kahn 2010; Oreopolous, von Wachter, and Heisz 2012). The help-wanted index has been used as a proxy for job vacancies in numerous studies (e.g., Shimer 2005).
} 
Despite their appeal at a conceptual level, counts of listings in disciplinary employment services may not be a perfect measure of the labor demand for new doctorate recipients, for several reasons. First, these counts typically include listings for positions of all ranks, including positions for full professors as well as those for assistant professors. Second, a given listing may be published multiple times (for instance, in consecutive months), and in some cases the annual total number of listings that is available includes only new listings whereas in other cases the total includes both new and repeat listings. Third, a given listing can advertise multiple vacancies; in some cases the figure that I collected is the total number of listings whereas in others the figure is the total number of vacancies. Because for most fields I had access to summary tabulations rather than the individual listings, I had to accept differences across fields in definitions. However, in the measures I chose or constructed I was able to achieve consistency over time within each field.

Another potential concern is that some types of jobs that are of interest to new doctorate recipients in a given field may not be well represented in the listings. In particular, the job listings may disproportionately represent academic jobs. Almost all academic vacancies should be included in the listings, but some non-academic vacancies may not be included in the listings. ${ }^{5}$ However, almost three-fourths (74 percent) of graduates in these fields (combined) went into academic employment after graduation. ${ }^{6}$ Furthermore, in economics—-the field with

\footnotetext{
${ }^{5}$ I expect that nearly all academic vacancies are included in these listings in order to comply with university antidiscrimination provisions and to satisfy the professional obligation to advertise open positions. For example, the Ethics Guide of the American Political Science Association (APSA) reads: "It is a professional obligation of all political science departments to list in the APSA Personnel Service Newsletter all positions for which they are recruiting at the Instructor, Assistant, and Associate Professor levels. In addition, the listing of openings at the Full Professor level is strongly encouraged. It is also a professional obligation for departments to list temporary and visiting positions" (quoted in Brintnall 2005).

${ }^{6}$ The share of graduates going into academic employment by field (among those with definite plans at the time of graduation): anthropology (60\%), classics (88\%), economics (61\%), English (81\%), history (76\%), philosophy (83\%), and political science (76\%) [author's calculations from SED data for 1975-2005 doctorate recipients].
} 
the largest share of graduates going into non-academic employment—-the number of nonacademic listings is highly correlated with the number of academic listings over the period 19752005 (correlation coefficient: 0.79). Thus, even if the job listings disproportionately represent academic jobs, the number of listings may still be an adequate measure of labor demand overall (including non-academic vacancies).

The time-series data on job listings is presented in Figure 1. Panel A shows the annual number of job listings by field. Panel B normalizes the number of job listings by the fieldspecific average over 1984-2002 (the period over which listings are available for all fields); the scale is set so that the field-specific average is 10 . Panel B indicates that time-series trends are similar across fields. The raw correlation between any two fields in the normalized listings ranges from 0.34 to 0.92 . The standard deviation of normalized listings varies across fields from 1.72 to 3.21 with an average of 2.07. The number of job listings in a given field is similar in consecutive years, with a correlation coefficient in normalized listings of 0.83 . I use the normalized measure of job listings in the empirical analysis because it isolates the variation over time within a field and because it makes fields comparable regardless of size.

Given the measurement concerns, I provide two pieces of evidence that the number of job listings is a credible measure of the labor demand for new doctorate recipients. First, job listings are correlated with fiscal variables that are plausibly related to labor demand. As shown in Table 3 , variation over time in job listings is correlated with the national unemployment rate (negatively), state appropriations per student at public universities (positively), expenditures per student at public universities (positively), and faculty salaries (positively). When faculty salaries are examined by rank, salaries of junior faculty (assistant professor, instructor, and lecturer) and 
salaries of senior faculty (associate professor and full professor) are positively correlated with the number of job listings.

Second, job listings are positively correlated with job outcomes of new PhD recipients. ${ }^{7}$ To measure the job outcomes of new $\mathrm{PhD}$ recipients, I use their responses to questions in the SED regarding postgraduation plans. The survey asks whether a graduate has made a definite commitment for work or further training (such as a postdoctoral position) and (for those with a definite commitment) the type of employer. From the responses I construct indicator variables for four job outcomes: (1) work/training with any employer, (2) work/training with a U.S. employer, (3) work/training with an academic employer, and (4) work/training with a U.S. academic employer. I estimate a set of regressions in which a given indicator variable is a function of the number of job listings in the year of completion and controls for field, rank and size of the doctoral program, TTD, and demographic characteristics.

As shown in Table 4, the estimated coefficient on job listings is positive and statistically significant in the regression for each job outcome. For the first outcome, the estimated coefficient implies that an increase in job listings of 10 percent increases the share of graduates having work/training with any employer by 1.2 percentage points. The estimated coefficients for the other three outcomes—which focus on specific segments of the market—are qualitatively similar (ranging from 1.0 to 1.2). Taken together, the evidence in Table 3 and Table 4 indicates that the number of job listings is a credible measure of labor demand for new doctorate recipients.

\footnotetext{
${ }^{7}$ In related evidence, Oyer (2006) showed that the number of academic job listings in economics at the time of completion is correlated with the quality of initial placement.
} 


\section{Empirical Approach}

\subsection{Econometric Model}

I use a duration model to estimate the impact of labor demand on TTD. A duration model is appropriate because we are considering factors associated with the timing of an event (namely, completing a doctoral program). Because the counts of job listings are constructed on an annual basis, I use a discrete-time model. For each graduate, I use the SED data to determine the academic year of entry to graduate school $\left(t_{e}\right)$ and the academic year of the $\operatorname{PhD}\left(t_{p}\right) .^{8}$ Then I compute TTD as the number of academic years between entry and completion $\left(t_{p}-t_{e}+1\right)$. As discussed by Jenkins (1995) and Singer and Willett (1993), discrete-time duration models are convenient to specify (they accommodate both time-varying and fixed covariates) and easy to estimate with standard statistical packages. ${ }^{9}$ Following their advice, I arrange the student data with one observation per (academic) year for each student. These data are then matched by year and field to the number of job listings.

For a student in field $f$ who enters graduate school in academic year $t_{0 i}$, I specify the probability of completing the $\mathrm{PhD}$ in Year $t$ of the program (if the student has not yet graduated) as a function of time-varying and fixed covariates using the logistic form:

$$
\lambda\left(t_{0 i}, t\right)=\frac{\exp \left[y_{i}\left(t_{0 i}, t\right)\right]}{1+\exp \left[y_{i}\left(t_{0 i}, t\right)\right]} \text {, where } y_{i}\left(t_{0 i}, t\right)=\theta+\psi_{t}+\gamma^{\prime} X_{i}+\beta Z_{f}\left(t_{0 i}+t-1\right) \text {. }
$$

In this equation, $\theta$ is a constant; $\psi_{t}$ is a fixed effect for Year $t$ of the program; $X_{i}$ is a vector of time-invariant student and program characteristics; and $Z_{f}\left(t_{0 i}+t-1\right)$ is the number of job listings for field $f$ in academic year $t_{0 i}+t-1$, when the student was in Year $t$ of the program.

\footnotetext{
${ }^{8}$ As noted in the Appendix, academic years are defined for this analysis as going from August of one calendar year through July of the following calendar year. For defining the academic year of PhDs, I assign PhDs awarded in the fall (August through December) to the prior academic year because in these cases students have typically completed the degree requirements by the end of July.

${ }^{9}$ Another paper that uses a discrete-time duration model is Ham and Rea (1987).
} 
The estimation sample contains students who graduated between 1975 and 2008 and who had TTD between 4 and 15 years. Each student contributes one observation for each academic year spent in the program, starting with Year 4. I don't include observations for Years 1-3 because the probability of completion in these years is essentially zero. An implication of this restriction is that the estimated effect of labor demand is based primarily on the dissertation stage of doctoral programs. This is sensible because labor demand is likely to have little influence on student progress during the coursework stage.

I match the student data to the data on job listings by field and academic year, which are available for 1975-2005 or a portion of this period for some fields. After the match, some student-year observations have missing data on job listings; for example, a philosophy student who entered in 1998 and graduated in 2005 would have missing data on job listings for academic years 2003-2005 because the time series of philosophy job listings ends in 2002. To be included in the estimation sample, I require that students have data on jobs listings for their fourth year; for later years, student-year observations with missing data on job listings are dropped from the sample. As a result, some students (2.3 percent) in the estimation sample have incomplete spells; most (97.7 percent) have completed spells.

For the completed spells, we observe graduation in academic year $t_{0 i}+t_{i}^{*}-1$; thus, TTD is $t_{i}^{*}$ years. The probability of the completed spell is

$$
g_{i}\left(t_{0 i}, t_{i}^{*}\right)=\left\{\prod_{t=4}^{t_{i}^{*}-1}\left[1-\lambda_{i}\left(t_{0 i}, t\right)\right]\right\} \lambda_{i}\left(t_{0 i}, t_{i}^{*}\right)
$$

For the incomplete spells, TTD is right censored at $\bar{t}_{i}$ (i.e., we know only that TTD exceeds $\bar{t}_{i}$ ). The contribution to the likelihood function for these cases is

$$
\left[1-G\left(t_{0 i}, \bar{t}_{i}\right)\right]=\prod_{t=4}^{\bar{t}_{i}}\left[1-\lambda_{i}\left(t_{0 i}, t\right)\right]
$$

The likelihood function is then 


$$
L=\prod_{i \in C} g_{i}\left(t_{0 i}, t_{i}^{*}\right) \prod_{i \in I N}\left[1-G\left(t_{0 i}, \bar{t}_{i}\right)\right],
$$

where $C$ denotes completed spells and $I N$ denotes incomplete spells. Parameter estimates are obtained by maximizing $L$ with respect to the parameters. This is done by estimating a logit regression model with the dependent variable equal to 1 for the year the student graduates and equal to 0 for other years. Because the measure of job listings does not vary across student-year observations in the same year and field, I compute standard errors that allow for correlation in the error term within cells defined by year and field.

To translate the coefficient estimates into effects on TTD, I compute the marginal effect of job listings on expected TTD. Given the parameter estimates, expected TTD is

$$
E(T T D)=\sum_{t=4}^{15} t \cdot g\left(t_{0}, t\right) .
$$

For this calculation, I set the $X$ variables at their mean values. The effect of changing labor demand on expected TTD is obtained by numerically differentiating this equation with respect to the number of job listings. The interpretation of this effect is how expected TTD would respond to a permanent increase in the number of job listings.

\subsection{Implementation}

Due to the requirement that sample members have completed a $\mathrm{PhD}$ by 2008, the completion hazard is artificially high for the years leading up to 2008. As a result, the time trend in the completion hazard involves a form of selection bias. This is illustrated in Figure 2, which plots (using the solid lines) the completion hazard over time separately for students in the 5th, 7th, and 9th years of their doctoral programs. For Year 5, for example, the completion hazard increases sharply after 2001. The reason is that the composition of the sample changes over time, with the sample in later years having a shorter average TTD. In 2005, for instance, the 
sample of students in Year 5 is those with TTD of 8 years or less. By contrast, the sample of students in Year 5 for 2002 is those with TTD of 11 years or less.

For Year 5, the first year that is subject to selection bias is 1999 because the sample for that year is students with TTD of 14 years or less. The first year that is subject to selection bias varies by year in program - a pattern that is evident in Figure 2. Generically, for Year $X$, the last year that is not subject to selection bias is $2008-(15-X)$; this is 1998 for Year 5, 2000 for Year 7, and 2002 for Year 9.

I use two approaches to eliminate selection bias from the estimates. The first approach is to remove from the estimation sample the student-year observations in cells that are subject to selection bias. The second approach is to group the student-year observations into cells defined by field $(f)$, academic year $(y)$, and year in program $(X)$ and adjust the cells that are subject to selection bias. Specifically, for each cell I compute the completion rate and multiply it by $\operatorname{Pr}(T T D \leq Z \mid f ; X)$, where $Z=X+(2008-y)$. For Year 5, for example, the factors are $\operatorname{Pr}(T T D \leq 8)$ for 2005 and $\operatorname{Pr}(T T D \leq 11)$ for 2002. The adjustment factors are estimated using the student-year observations in cells that are not subject to selection bias. This multiplicative adjustment removes the selection bias by converting the completion rate for the cell from one for the observed sample (those who finish by 2008) to one for all students with TTD of 15 years or less (including those who finish after 2008). As illustrated in Figure 2 (with the dashed lines), this adjustment removes the steep upward trend in the completion hazards at the end of the sample period.

The first approach, because it retains the student-level detail in the estimation sample, has the advantage of allowing controls for individual characteristics such as demographics and financial support. A disadvantage of this approach is that, by discarding observations in cells 
subject to selection bias, it reduces coverage of the years at the end of the sample period. The second approach, by contrast, covers the entire sample period. But because it requires collapsing the data into cells, estimation under this approach does not allow for individual-level controls.

In both the student-level model and group-level model, the key explanatory variable is the number of job listings relative to the field-specific mean (scaled so that the field-specific average is 10). The other time-varying explanatory variables are year-in-program indicators (single years 4-13 and years 14 and 15 combined). Both models include controls for field. The student-level model includes additional time-invariant explanatory variables: gender, citizenship/race, age at graduate entry, primary source of support, and rank and size of the doctoral program. ${ }^{10}$ I do not include primary source of support in the baseline student-level model because support might be endogenous to labor demand, but I include it in another specification as a robustness check.

The dependent variable in the student-level model is a binary variable indicating whether the student completed the PhD in the year of the observation. In the group-level model, by contrast, the dependent variable is the completion rate in the year for the cell (i.e., the proportion of students in the cell who completed the $\mathrm{PhD}$ in the year). As a result, for the group-level model a linear specification is used instead of the logit specification that is used for the studentlevel model. Given the differences in dependent variable and functional form, the coefficients for the student-level and group-level models are not comparable. However, the marginal effects of job listings on expected TTD are constructed to be comparable: In both models, the marginal effects are for an increase in job listings of 10 percent. In order to produce results that are

\footnotetext{
${ }^{10}$ Although program rank and size can vary over time for a given department, they are considered time-invariant explanatory variables because of how they are assigned to students (see the Appendix).
} 
comparable to those from the student-level model, the group-level regressions are weighted by the number of students in each cell.

\section{Results}

\subsection{Main Results}

Table 5 presents the estimated effects of job listings in regressions that adjust for selection. In both the student-level model and the group-level model, the estimates indicate that the number of job listings is not correlated with the probability of completion and expected TTD. The first column of the table presents the results from my preferred version of the student-level model, which includes individual-level controls. In this model, the estimated coefficient on job listings is not significantly different from zero and the estimated marginal effect of an increase in job listings of 10 percent is close to zero (-0.007 year). In the group-level model (shown in the third column), the estimated marginal effect is also close to zero (-0.005 year).

To facilitate another comparison of the student-level and group-level models, the second column of the table reports results from an alternative version of the student-level model that does not include the individual-level controls. In this version, the estimated marginal effect is also close to zero (0.005 year). Summarizing, the three specifications reported in Table 5 have a consistent finding: labor demand (as measured by the number of job listings) is not correlated with the probability of completion and expected TTD.

Table 6 presents estimates separately by field. I compute these estimates by replacing the job-listings variable in the baseline specification with a full set of interactions between job listings and field indicators. These estimates are presented for the student-level and group-level models that adjust for selection. Consistent with the overall results, the estimated coefficient on job listings is not significantly different from zero in both models for three fields (anthropology, 
classics, and philosophy). History is the only field for which the estimated coefficient on job listings is statistically significant and the same sign in both models. For this field, the estimated marginal effect of an increase in job listings of 10 percent is a decrease in expected TTD of 0.040 year (in the group-level model) or 0.087 year (in the student-level model).

\subsection{Adjusting for Selection}

Table 7 shows the importance of adjusting for selection in estimating the effect of job listings on TTD. The table includes results from regressions that do not adjust for selection alongside those from regressions (those reported in Table 5) that adjust for selection. In both the student-level model and group-level model, adjusting for selection has a large impact on the results. In the student-level model without adjusting for selection, the estimated coefficient on job listings is positive and statistically significant, and the estimated marginal effect of an increase in job listings of 10 percent is a decrease in expected TTD of 0.068 year (about 0.82 month). Adjusting for selection reduces the magnitude of the estimated coefficient so that it is no longer statistically significant and the estimated marginal effect is close to zero (-0.007 year). The pattern of results is similar in the group-level model, with the selection adjustment reducing the estimated marginal effect from -0.061 year to -0.005 year.

Comparing the results from specifications with and without the adjustment for selection suggests that selection bias creates the apparent association between job listings and expected TTD in the specifications without the adjustment. The role of selection bias in this association is driven by artificially large completion hazards over the final 8 years of the sample period (see Figure 2), when job listings were above their historical average in most fields (see Figure 1). Once we adjust for selection, the estimated effect of job listings on expected TTD is essentially zero. 


\subsection{Robustness Checks}

This section reports the results of several robustness checks that largely validate the main results. Table 8 presents the results of specifications involving lags and leads in the effect of job listings. For these specifications, I replace the variable for the number of job listings in the current year with a variable for the number of job listings in a prior year (for the lag specifications) or a future year (for the lead specifications). I continue to use the student-level and group-level models that adjust for selection.

The lag specifications do not contain much evidence of delayed effects of labor demand on completion timing: The estimated coefficient of lagged job listings is not significantly different from zero in five of the six results (three lags each for the student-level and group-level models). The only instance in which lagged job listings is statistically significant is the third lag in the group-level model.

The lead specifications are relevant for detecting problems with identification. If the specification is correct, the probability of completion in year $t$ should not be "determined" by job listings in year $t+1$. This holds in five of the six results (three leads for each model type): The estimated coefficient on the lead of job listings is not significantly different from zero. The exception is the third lead of job listings in the student-level model.

The next set of robustness checks address concerns about omitted-variables bias. As discussed in Section 4.2, the baseline (student-level) model includes controls for demographics but does not include controls for financial support or student quality. The estimates reported in Table 9 demonstrate that including controls for financial support and student quality does not change the main results. Columns 2 and 3 address the impact of adding a control for primary 
source of support to the student-level model. ${ }^{11}$ With or without source of support as a control, the estimated marginal effect of job listings on expected TTD is not significantly different from zero. The estimated effects of source of support on the probability of completion are in the expected direction: Compared with using personal funds, each of the major sources of support (teaching assistantship, research assistantship, and fellowship) is associated with a higher probability of completion (shorter TTD).

As a proxy for student ability, I use a measure of the admissions selectivity of each student's bachelor's (BA) institution. This measure comes from Barron's Profiles of American Colleges (1992) and is available for students who received their BA degrees from a U.S. institution (78 percent of the students in my sample). The Barron's guide groups institutions into categories based on the degree of competitiveness in their admissions, ranging from "most competitive" to "noncompetitive." This proxy for student ability captures peer quality at the undergraduate level in addition to admissions selectivity per se.

Columns 4 and 5 of Table 9 show the results of including this proxy for student ability in the student-level model estimated on the sample of students who received their BA from a U.S. institution. Adding BA selectivity results in little change in the estimated effect of job listings: With or without BA selectivity as a control, the estimated marginal effect of job listings on expected TTD is not significantly different from zero. The effects of BA selectivity on completion are in the expected direction: The probability of completion is higher (TTD is lower) for students who attended more-selective BA institutions. Finally, the specification reported in column 6 includes controls for both BA selectivity and primary source of support. As with the

\footnotetext{
${ }^{11}$ The sample used for these specifications is somewhat smaller than the full sample because primary source of support was collected in the SED starting with doctorates awarded in 1977.
} 
other specifications that include these controls, the estimated effect of job listings on expected TTD is not significantly different from zero.

\section{Conclusion}

The main finding from the empirical analysis is that labor demand (as measured by the number of job listings) is not correlated with the probability of completion and expected TTD. There are several potential reasons for the absence of a relationship. First, students may not be completely free to adjust their completion timing. Their advisors may push them to complete their degrees when they are ready (i.e., without regard to labor demand) in order to avoid a large number of almost-finished $\mathrm{PhD}$ students in their department. Second, even though job listings are relatively easy for students to access, what the listings reveal about labor demand may not be immediately clear to students. Obtaining an accurate assessment of current labor demand may require a substantial time commitment, and students might be unwilling to make such a time commitment if they are not close to finishing their dissertations. Third, the absence of a relationship may be due to measurement error in job listings as a measure of labor demand for new doctorate recipients. Although I cannot rule out measurement error, the evidence presented in Section 3.2 indicates that the annual number of job listings in a field is a credible measure of labor demand.

The evidence presented here implies that cyclical variation in labor demand in the academic labor market is not responsible for changes over time in TTD within fields. The evidence is also relevant for institutional policies that set limits on the number of years that $\mathrm{PhD}$ students may receive institutional funding. The results here imply that there is no empirical basis for adjusting those limits based on the current level of labor demand. Institutions concerned about long TTD in PhD programs can consider a range of factors including program 
characteristics, financial support, and student composition, following the findings of earlier research on TTD and completion rates (e.g., Ehrenberg and Mavros 1995; Ehrenberg et al. 2007; Groen et al. 2008).

The findings from this analysis also carry an implication regarding the responsiveness of academic labor markets to short-run changes in demand. The finding that an increase in labor demand is not associated with an increase in the probability of completion implies that the completion behavior of existing students does not contribute to the overall short-run elasticity of supply in the labor market for humanities and social-science doctorates. Instead, the supply elasticity must reflect only the responses of doctorate holders who are not currently working, those working in the non-academic sector, and those working in other countries. 


\section{References}

Abedi, Jamal, and Ellen Benkin. 1987. “The Effects of Students’ Academic, Financial, and Demographic Variables on Time to the Doctorate.” Research in Higher Education 27 (1): 3-14.

American Philosophical Association. 2004. “Appendix to Board Minutes.” Proceedings and Addresses of the American Philosophical Association 77 (5): 111-149.

Barron’s Profiles of American Colleges. 1992. 19th edition. Hauppauge, NY: Barron’s Educational Series, Inc.

Bowen, William G., and Neil L. Rudenstine. 1992. In Pursuit of the PhD. Princeton, NJ: Princeton University Press.

Breneman, David W. 1976. “The Ph.D. Production Process.” In Joseph T. Froomkin, Dean T. Jamison, and Roy Radner (eds.), Education as an Industry (pp. 3-52). Cambridge, MA: Ballinger.

Brintnall, Michael. 2005. “Academic Jobs in Political Science: A Review of Listings with the APSA Jobs Service.” PS: Political Science and Politics 38 (1): 125-127.

Council of Graduate Schools. 2010. Ph.D. Completion and Attrition: Policies and Practices to Promote Student Success. Washington, DC: Council of Graduate Schools.

Ehrenberg, Ronald G. 1992. “The Flow of New Doctorates.” Journal of Economic Literature 30 (2): 830-875.

Ehrenberg, Ronald G., George H. Jakubson, Jeffrey A. Groen, Eric So, and Joseph Price. 2007. “Inside the Black Box of Doctoral Education: What Program Characteristics Influence Doctoral Students’ Attrition and Completion Probabilities?” Educational Evaluation and Policy Analysis 29 (2): 134-150. 
Ehrenberg, Ronald G., and Panagiotis G. Mavros. 1995. “Do Doctoral Students’ Financial Support Patterns Affect Their Times-to-Degree and Completion Probabilities?” Journal of Human Resources 30 (3): 581-609.

Ehrenberg, Ronald G., Harriet Zuckerman, Jeffrey A. Groen, and Sharon M. Brucker. 2009. Educating Scholars: Doctoral Education in the Humanities. Princeton, NJ: Princeton University Press.

Espenshade, Thomas J., and German Rodriguez. 1997. “Completing the Ph.D.: Comparative Performances of U.S. and Foreign Students.” Social Science Quarterly 78 (2): 593-605.

Goldberger, Marvin L., Brendan A. Maher, and Pamela E. Flattau, eds. 1995. Research Doctorate Programs in the United States: Continuity and Change. Washington, DC: National Academies Press.

Groen, Jeffrey A., George H. Jakubson, Ronald G. Ehrenberg, Scott Condie, and Albert Y. Liu. 2008. “Program Design and Student Outcomes in Graduate Education.” Economics of Education Review 27 (2): 111-124.

Ham, John C., and Samuel A. Rea Jr. 1987. “Unemployment Insurance and Male Unemployment Duration in Canada.” Journal of Labor Economics 5 (3): 325-353.

Hoffer, Thomas B., Vincent Welch Jr., Kristy Webber, Kimberly Williams, Brian Lisek, Mary Hess, Daniel Loew, and Isabel Guzman-Barron. 2006. Doctorate Recipients from United States Universities: Summary Report 2005. Chicago: National Opinion Research Center. Jenkins, Stephen P. 1995. “Easy Estimation Methods for Discrete-Time Duration Models.” Oxford Bulletin of Economics and Statistics 57 (1): 129-138. 
Jones, Lyle V., Gardner Lindzey, and Porter E. Coggeshall, eds. 1982a. An Assessment of Research-Doctorate Programs in the United States: Humanities. Washington, DC: National Academies Press.

Jones, Lyle V., Gardner Lindzey, and Porter E. Coggeshall, eds. 1982b. An Assessment of Research-Doctorate Programs in the United States: Social and Behavioral Sciences. Washington, DC: National Academies Press.

Kahn, Lisa B. 2010. “The Long-Term Labor Market Consequences of Graduating from College in a Bad Economy.” Labour Economics 17 (2): 303-316.

Messer, Dolores, and Stefan C. Wolter. 2010. “Time-to-Degree and the Business Cycle.” Education Economics 18 (1): 111-123.

National Center for Education Statistics. 2007. Digest of Education Statistics 2006 (NCES 2007017). Washington, DC: U.S. Government Printing Office.

Oreopolous, Philip, Till von Wachter, and Andrew Heisz. 2012. “The Short- and Long-Term Career Effects of Graduating in a Recession.” American Economic Journal: Applied Economics 4 (1): 1-29.

Ostriker, Jeremiah P., Paul W. Holland, Charlotte V. Kuh, and James A. Voytuk, eds. 2010. A Data-Based Assessment of Research-Doctorate Programs in the United States. Washington, DC: National Academies Press.

Oyer, Paul. 2006. "Initial Labor Market Conditions and Long-Term Outcomes for Economists.” Journal of Economic Perspectives 20 (3): 143-160.

Rizzo, Michael J. 2006. “State Preferences for Higher Education Spending: A Panel Data Analysis, 1977-2001.” In Ronald G. Ehrenberg (ed.), What’s Happening to Public Higher Education? (pp. 3-36). Westport, CT: Praeger. 
Shimer, Robert. 2005. "The Cyclical Behavior of Equilibrium Unemployment and Vacancies.” American Economic Review 95 (1): 25-49.

Siegfried, John J. 2001. "Report of the Director, Job Openings for Economists." American Economic Review 91 (2): 492-494.

Siegfried, John J., and Wendy A. Stock. 2001. "So You Want to Earn a Ph.D. in Economics? How Long Do You Think It Will Take?” Journal of Human Resources 36 (2): 364-378.

Singer, Judith D., and John B. Willett. 1993. “It’s About Time: Using Discrete-Time Survival Analysis to Study Duration and the Timing of Events.” Journal of Educational Statistics 18 (2): 155-195.

Stephan, Paula, and Jennifer Ma. 2005. “The Increased Frequency and Duration of the Postdoctoral Career Stage.” American Economic Review 95 (2): 71-75.

Tuckman, Howard, Susan Coyle, and Yupin Bae. 1990. On Time to the Doctorate: A Study of the Increased Time to Complete Doctorates in Science and Engineering. Washington, DC: National Academies Press. 
Figure 1. Job Listings by Field, 1975-2005

(A) Number of listings

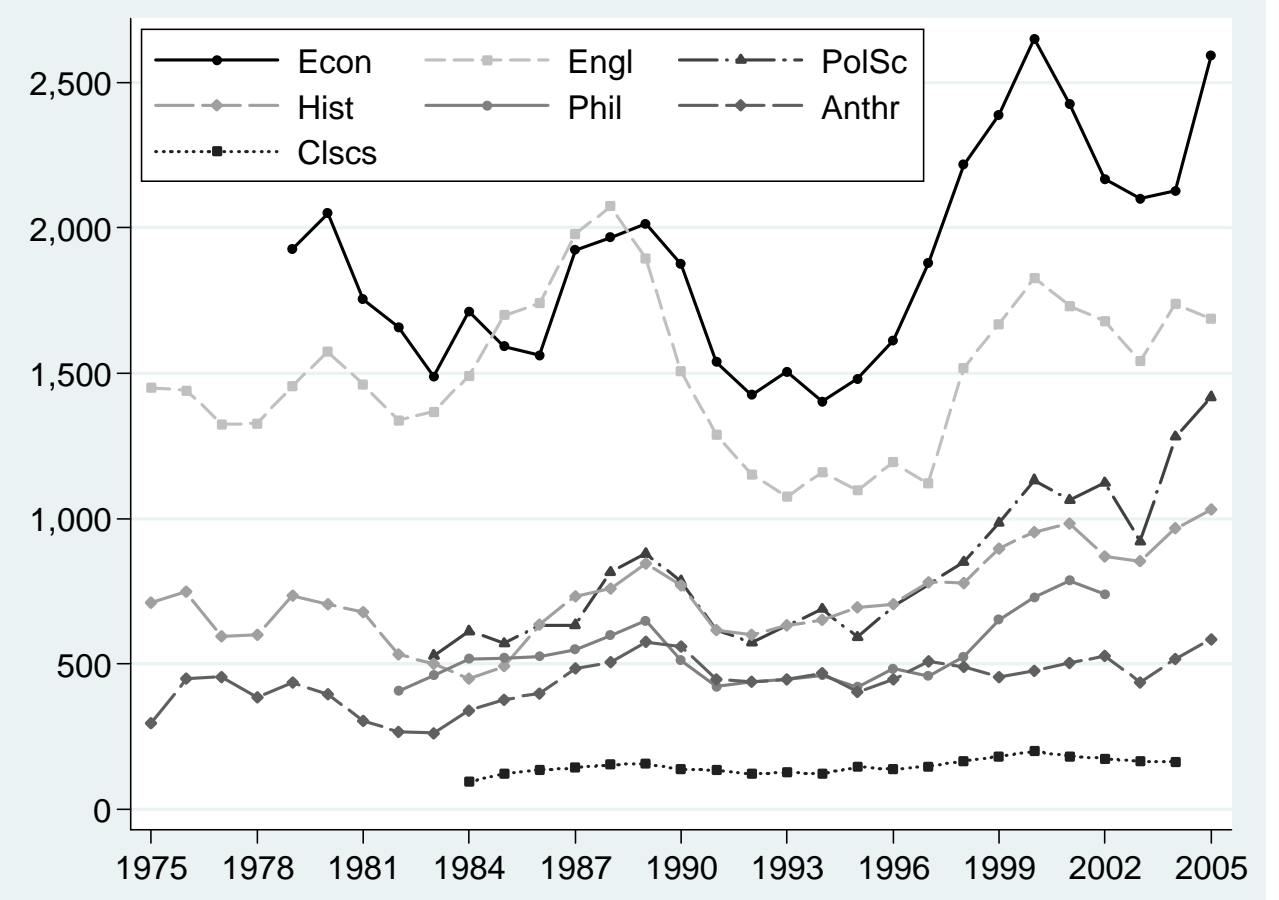

(B) Number of listings relative to field-specific average

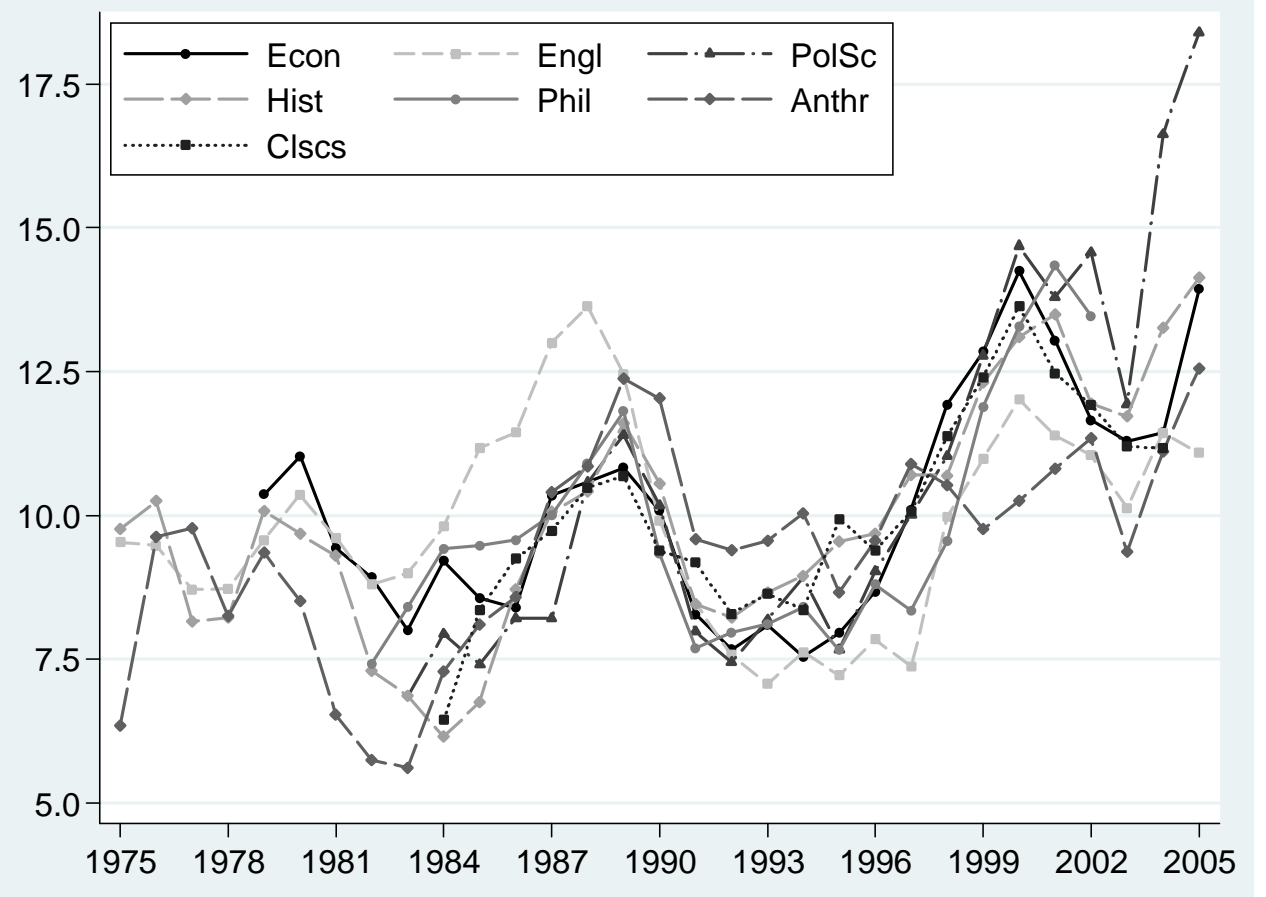

Source: See the Appendix.

Notes: "Anthr"=anthropology. "Clscs"=classics. "Econ”=economics. "Engl”=English.

"Hist"=history. "Phil”=philosophy. "PolSc"=political science. 
Figure 2. Adjustment for Selection

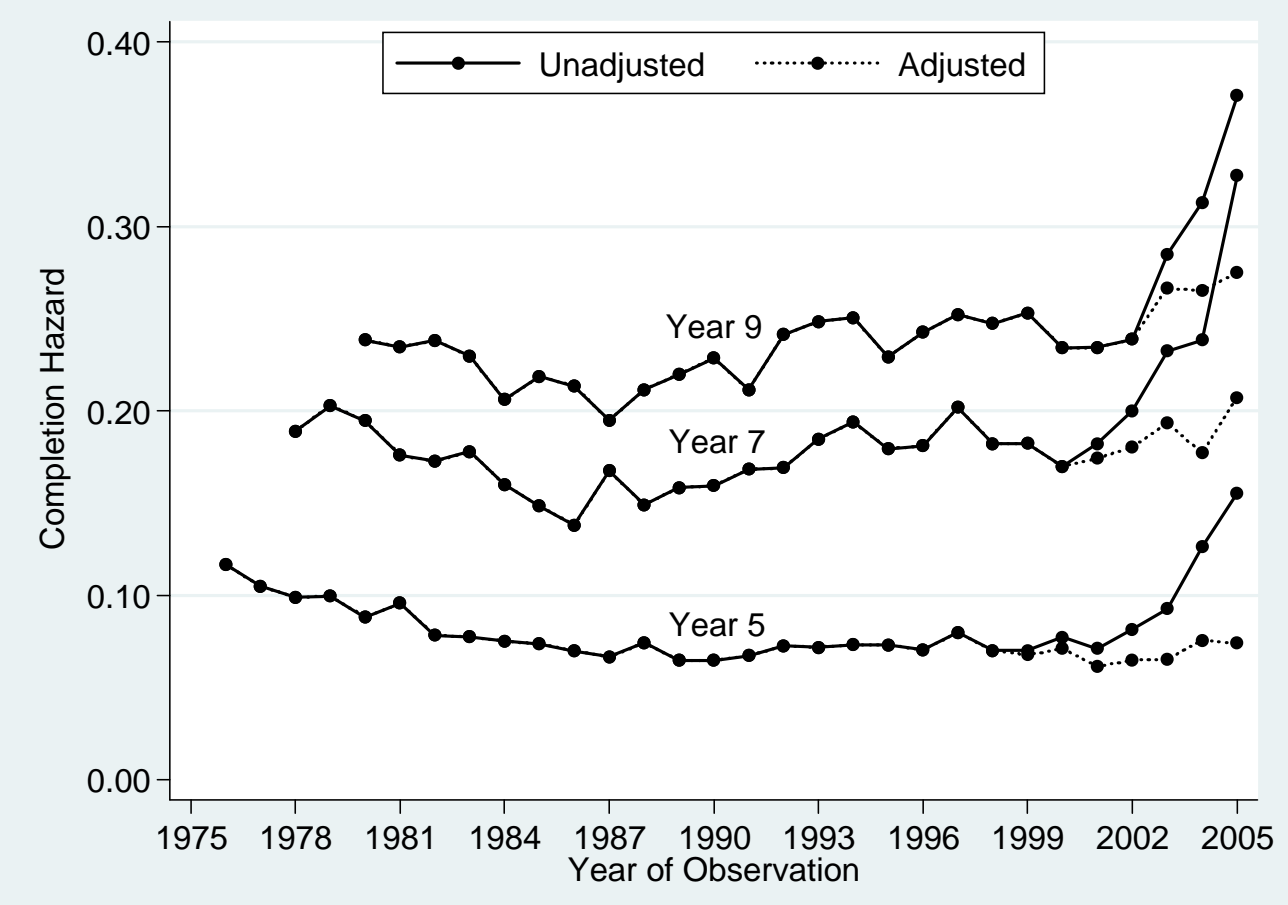


Table 1. Characteristics of Doctorate Recipients, 1975-2008

\begin{tabular}{lrrr}
\hline \hline & & Median & Mean \\
Characteristic & & & \\
\hline Gender & 62.12 & 8.67 & 9.95 \\
Men & 37.88 & 9.26 & 10.88 \\
Women & & & \\
Citizenship/Race & 21.82 & 8.42 & 9.31 \\
Non-U.S. citizen & 8.12 & 9.25 & 10.80 \\
U.S. citizen, non-white & 68.54 & 8.92 & 10.56 \\
U.S. citizen, white & 1.52 & 8.67 & 10.04 \\
Missing & & & \\
Primary Source of Support & 29.61 & 8.25 & 9.22 \\
Teaching assistantship & 4.90 & 7.67 & 8.57 \\
Research assistantship & 22.76 & 7.92 & 9.03 \\
Fellowship & 29.86 & 10.76 & 12.56 \\
Personal funds & 3.54 & 9.67 & 11.16 \\
Other source & 9.33 & 9.67 & 11.01 \\
Missing & & & \\
Age at Graduate Entry & 7.32 & 9.67 & 11.48 \\
21 or younger & 26.11 & 8.67 & 10.20 \\
22 & 18.90 & 8.67 & 10.06 \\
23 & 12.86 & 8.75 & 10.05 \\
24 & 8.78 & 8.92 & 10.23 \\
25 & 6.38 & 8.92 & 10.22 \\
26 & 4.37 & 9.09 & 10.27 \\
27 & 5.38 & 9.25 & 10.43 \\
28 to 29 & 5.05 & 9.34 & 10.59 \\
30 to 33 & 4.84 & 9.50 & 10.36 \\
34 or older & 100.00 & 8.92 & 10.30 \\
Total & & & \\
\hline &
\end{tabular}

Notes: N=119,961. Tabulation covers doctorate recipients in seven fields: anthropology, classics, economics, English, history, philosophy, and political science. Tabulation of financial support is based on 1977-2008 because primary source of support was not requested by the survey prior to 1977. 
Table 2. Time to Degree by Field, 1975-2008 Doctorate Recipients

\begin{tabular}{lrrrrrrr}
\hline \hline Field & Median & Mean & $\begin{array}{r}\text { 25th } \\
\text { \%ile }^{\mathrm{a}}\end{array}$ & $\begin{array}{r}\text { 75th } \\
\text { \%ile }\end{array}$ & $\begin{array}{r}\text { 75th } \\
-25 \text { th }\end{array}$ & $\mathrm{N}$ & N/year \\
\hline Anthropology & 9.76 & 11.12 & 7.67 & 12.92 & 5.25 & 13,168 & 387.3 \\
Classics & 8.34 & 9.87 & 6.67 & 11.34 & 4.67 & 1,916 & 56.4 \\
Economics & 7.25 & 8.37 & 5.67 & 9.92 & 4.25 & 26,711 & 785.6 \\
English & 9.67 & 11.11 & 7.25 & 12.93 & 5.68 & 27,537 & 809.9 \\
History & 9.75 & 11.37 & 7.67 & 13.26 & 5.59 & 25,018 & 735.8 \\
Philosophy & 8.67 & 10.04 & 6.67 & 11.67 & 5.00 & 9,407 & 276.7 \\
Political science & 8.75 & 10.01 & 6.67 & 11.76 & 5.09 & 16,204 & 476.6 \\
\hline \hline
\end{tabular}

aPercentile. 
Table 3. Correlation of Job Listings with Fiscal Variables, 1975-2005

\begin{tabular}{lccccc}
\hline Fiscal variable & Mean & Coeff. & S.E. & $\mathrm{R}^{2}$ & $\mathrm{~N}$ \\
\hline Unemployment rate $_{\text {State appropriations per student }}^{\mathrm{a}}$ & 6.12 & $-0.872^{*}$ & 0.161 & 0.33 & 185 \\
College expenditures per student $^{\mathrm{a}}$ & 10.96 & $2.221^{*}$ & 0.360 & 0.38 & 147 \\
Faculty salaries $^{\mathrm{a}}$ & & $0.246^{*}$ & 0.071 & 0.16 & 147 \\
$\quad$ All faculty & 62.45 & $0.272^{*}$ & 0.066 & 0.28 & 152 \\
Full professor & 82.81 & $0.205^{*}$ & 0.039 & 0.37 & 152 \\
Associate professor & 61.39 & $0.318^{*}$ & 0.070 & 0.32 & 152 \\
Assistant professor & 50.84 & $0.343^{*}$ & 0.078 & 0.32 & 152 \\
Instructor & 41.93 & $0.207^{*}$ & 0.038 & 0.35 & 152 \\
Lecturer & 44.15 & $0.621^{*}$ & 0.152 & 0.33 & 152 \\
\hline \hline
\end{tabular}

Notes: Each row comes from a separate regression of the number of job listings (mean $=10.0$ ) on the fiscal variable and a set of indicators for field. The unit of observation is a field-year. Standard errors account for clustering by year. See the Appendix for details on the fiscal variables.

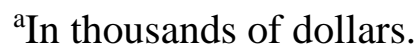

${ }^{*} p<.05$ 
Table 4. Predicting Job Outcomes of New Doctorate Recipients, 1975-2005

\begin{tabular}{|c|c|c|}
\hline Job outcome & Mean & $\begin{array}{l}\text { Coeff. } \\
\text { on Job } \\
\text { Listings }\end{array}$ \\
\hline Work/training with any employer & 65.35 & $\begin{array}{l}1.201^{*} \\
(0.134)\end{array}$ \\
\hline Work/training with U.S. employer & 57.01 & $\begin{array}{l}1.214^{*} \\
(0.147)\end{array}$ \\
\hline Work/training with academic employer & 48.46 & $\begin{array}{c}0.998 * \\
(0.165)\end{array}$ \\
\hline Work/training with U.S. academic employer & 43.09 & $\begin{array}{l}1.029 * \\
(0.164) \\
\end{array}$ \\
\hline
\end{tabular}

Notes: Each row comes from a separate regression of the job outcome (an indicator multiplied by 100 ) on the number of job listings (mean=10.0), field, program rank, program size, TTD (15 categories), gender, citizenship/race, and age at $\mathrm{PhD}$ completion (8 categories). Sample size for each regression: 94,976 students. Standard errors (in parentheses) account for clustering by year and field.

$* p<.05$ 
Table 5. Effect of Job Listings on Completion Probabilities and Expected TTD

\begin{tabular}{lccc}
\hline Level & Student & Student & Group \\
Adjust for selection & Yes & Yes & Yes \\
Individual controls & Yes & No & No \\
\hline Coefficient & 0.0034 & -0.0025 & 0.0002 \\
Standard error & $(0.0067)$ & $(0.0060)$ & $(0.0005)$ \\
Marginal effect & {$[-0.0071]$} & {$[0.0053]$} & {$[-0.0046]$} \\
$\mathrm{N}$ & 361,838 & 361,838 & 1,755 \\
Students & 60,739 & 60,739 & - \\
\hline
\end{tabular}

Notes: Each column comes from a separate regression. All regressions include controls for field and year in program. Student-level regressions also include controls for program rank, program size, gender, race/citizenship, and age at graduate entry (10 categories). Standard errors account for clustering by year and field. Marginal effects on expected TTD are for an increase in job listings of 10 percent. The unit of observation for the student-level regressions is a student-year; the unit of observation for the group-level regressions is a cell defined by field, academic year, and year in program.

${ }^{*} p<.05$ 
Table 6. Effect of Job Listings by Field

\begin{tabular}{lcc}
\hline \hline Level & Student & Group \\
Adjust for selection & Yes & Yes \\
Individual controls & Yes & No \\
\hline Anthropology & 0.0139 & -0.0009 \\
& $(0.0137)$ & $(0.0011)$ \\
Classics & {$[-0.0287]$} & {$[0.0182]$} \\
& 0.0023 & -0.0036 \\
& $(0.0235)$ & $(0.0029)$ \\
Economics & {$[-0.0048]$} & {$[0.0881]$} \\
& $-0.0277^{*}$ & 0.0003 \\
English & $(0.0128)$ & $(0.0012)$ \\
& {$[0.0580]$} & {$[-0.0058]$} \\
History & -0.0236 & $-0.0027 *$ \\
& $(0.0132)$ & $(0.0012)$ \\
& {$[0.0497]$} & {$[0.0635]$} \\
Philosophy & $0.0460 *$ & $0.0022^{*}$ \\
& $(0.0083)$ & $(0.0007)$ \\
& {$[-0.0870]$} & {$[-0.0399]$} \\
Political science & 0.0199 & 0.0004 \\
& $(0.0110)$ & $(0.0007)$ \\
& {$[-0.0405]$} & {$[-0.0083]$} \\
& 0.0106 & $0.0014 *$ \\
& $(0.0069)$ & $(0.0006)$ \\
& {$[-0.0219]$} & {$[-0.0257]$} \\
\hline
\end{tabular}

Notes: Each column comes from a separate regression. Both regressions include controls for field and year in program. Student-level regressions also include controls for program rank, program size, gender, race/citizenship, and age at graduate entry (10 categories). Standard errors (in parentheses) account for clustering by year and field. Marginal effects on expected TTD (in brackets) are for an increase in job listings of 10 percent.

$* p<.05$ 
Table 7. Effect of Adjusting for Selection on the Estimated Effect of Job Listings

\begin{tabular}{lccccc}
\hline \hline Level & Student & Student & Student & Group & Group \\
Adjust for selection & No & Yes & Yes & No & Yes \\
Individual controls & Yes & Yes & No & No & No \\
\hline Coefficient & $0.0327^{*}$ & 0.0034 & -0.0025 & $0.0031^{*}$ & 0.0002 \\
Standard error & $(0.0084)$ & $(0.0067)$ & $(0.0060)$ & $(0.0011)$ & $(0.0005)$ \\
Marginal effect & {$[-0.0681]$} & {$[-0.0071]$} & {$[0.0053]$} & {$[-0.0614]$} & {$[-0.0046]$} \\
N & 434,749 & 361,838 & 361,838 & 1,755 & 1,755 \\
Students & 79,729 & 60,739 & 60,739 & - & - \\
\hline \hline
\end{tabular}

Notes: Each column comes from a separate regression. All regressions include controls for field and year in program. Student-level regressions also include controls for program rank, program size, gender, race/citizenship, and age at graduate entry (10 categories). Standard errors account for clustering by year and field. Marginal effects on expected TTD are for an increase in job listings of 10 percent. The unit of observation for the student-level regressions is a student-year; the unit of observation for the group-level regressions is a cell defined by field, academic year, and year in program.

${ }^{*} p<.05$ 
Table 8. Lags and Leads in the Effect of Job Listings

\begin{tabular}{lcc}
\hline \hline Level & Student & Group \\
Adjust for selection & Yes & Yes \\
Individual controls & Yes & No \\
\hline Lag: $\mathrm{t}-1$ & -0.0026 & -0.0001 \\
& $(0.0062)$ & $(0.0005)$ \\
& {$[0.0054]$} & {$[0.0019]$} \\
Lag: $\mathrm{t}-2$ & -0.0041 & 0.0001 \\
& $(0.0063)$ & $(0.0005)$ \\
& {$[0.0085]$} & {$[-0.0013]$} \\
Lag: $\mathrm{t}-3$ & 0.0040 & $0.0013^{*}$ \\
& $(0.0063)$ & $(0.0005)$ \\
& {$[-0.0082]$} & {$[-0.0258]$} \\
Lead: $\mathrm{t}+1$ & 0.0076 & 0.0004 \\
& $(0.0067)$ & $(0.0005)$ \\
& {$[-0.0160]$} & {$[-0.0077]$} \\
Lead: $\mathrm{t}+2$ & 0.0105 & 0.0004 \\
& $(0.0061)$ & $(0.0005)$ \\
Lead: $\mathrm{t}+3$ & {$[-0.0220]$} & {$[-0.0087]$} \\
& $0.0145^{*}$ & 0.0005 \\
& $(0.0060)$ & $(0.0005)$ \\
& {$[-0.0305]$} & {$[-0.0106]$} \\
\hline \hline
\end{tabular}

Notes: Each cell comes from a separate regression. All regressions include controls for field and year in program. Student-level regressions also include controls for program rank, program size, gender, race/citizenship, and age at graduate entry (10 categories). Standard errors (in parentheses) account for clustering by year and field. Marginal effects on expected TTD (in brackets) are for an increase in job listings of 10 percent.

${ }^{*} p<.05$ 
Table 9. Controlling for Financial Support and Student Quality

\begin{tabular}{|c|c|c|c|c|c|c|}
\hline \multirow[b]{2}{*}{ Variable } & \multirow{2}{*}{$\begin{array}{l}\text { All } \\
(1)\end{array}$} & \multicolumn{2}{|c|}{ PhD 1977-2008 } & \multicolumn{3}{|c|}{$\begin{array}{l}\text { BA from U.S. Institution } \\
\text { \& PhD 1977-2008 }\end{array}$} \\
\hline & & $(2)$ & (3) & $(4)$ & (5) & (6) \\
\hline \multirow[t]{3}{*}{ Job listings } & 0.0034 & 0.0025 & -0.0035 & 0.0109 & 0.0098 & 0.0033 \\
\hline & $(0.0067)$ & $(0.0066)$ & $(0.0063)$ & $(0.0073)$ & $(0.0071)$ & $(0.0065)$ \\
\hline & {$[-0.0071]$} & {$[-0.0052]$} & {$[0.0073]$} & {$[-0.0221]$} & {$[-0.0200]$} & {$[-0.0066]$} \\
\hline \multirow[t]{2}{*}{ Teaching assistantship } & & & $0.3483^{*}$ & & & $0.3754 *$ \\
\hline & & & $(0.0189)$ & & & $(0.0199)$ \\
\hline \multirow[t]{2}{*}{ Research assistantship } & & & $0.4292 *$ & & & $0.4813^{*}$ \\
\hline & & & $(0.0310)$ & & & $(0.0357)$ \\
\hline \multirow[t]{2}{*}{ Fellowship } & & & $0.3570 *$ & & & $0.3932 *$ \\
\hline & & & $(0.0264)$ & & & $(0.0276)$ \\
\hline Personal funds & & & - & & & - \\
\hline BA: Most competitive & & & & & - & - \\
\hline \multirow[t]{2}{*}{ BA: Highly competitive } & & & & & $-0.1005 *$ & $-0.0927 *$ \\
\hline & & & & & $(0.0193)$ & $(0.0194)$ \\
\hline \multirow[t]{2}{*}{ BA: Very competitive } & & & & & $-0.1415^{*}$ & $-0.1199 *$ \\
\hline & & & & & $(0.0194)$ & $(0.0189)$ \\
\hline \multirow[t]{2}{*}{ BA: Competitive } & & & & & $-0.1906^{*}$ & $-0.1754^{*}$ \\
\hline & & & & & $(0.0188)$ & $(0.0179)$ \\
\hline \multirow{2}{*}{$\begin{array}{l}\text { BA: Less competitive or } \\
\text { noncompetitive }\end{array}$} & & & & & $-0.1891^{*}$ & $-0.1675^{*}$ \\
\hline & & & & & $(0.0245)$ & $(0.0234)$ \\
\hline \multirow[t]{2}{*}{ BA: Unranked } & & & & & $-0.3844^{*}$ & $-0.3307^{*}$ \\
\hline & & & & & $(0.0515)$ & $(0.0514)$ \\
\hline Pseudo $\mathrm{R}^{2}$ & 0.125 & 0.128 & 0.131 & 0.133 & 0.134 & 0.138 \\
\hline $\mathrm{N}$ & 361,838 & 361,411 & 361,411 & 283,694 & 283,694 & 283,694 \\
\hline Students & 60,739 & 60,467 & 60,467 & 47,571 & 47,571 & 47,571 \\
\hline Mean TTD & 8.84 & 8.86 & 8.86 & 8.85 & 8.85 & 8.85 \\
\hline
\end{tabular}

Notes: All regressions are from student-level models that adjust for selection and include controls for field, year in program, program rank, program size, gender, race/citizenship, and age at graduate entry (10 categories). Standard errors (in parentheses) account for clustering by year and field. Marginal effects on expected TTD (in brackets) are for an increase in job listings of 10 percent. The unit of observation is a student-year.

$* p<.05$ 


\section{Appendix: Data Sources and Variable Definitions}

Definition of academic year. Unless otherwise noted, a "year" is an academic year. Academic year $t$ is defined as going from August of calendar year $t$ through July of calendar year $t+1$.

Rank and size of doctoral programs. Program rankings are based on the average rating of the scholarly quality of program faculty in National Research Council assessments of doctoral programs in 1981 and 1993 (Jones, Lindzey, and Coggeshall 1982a, 1982b; Goldberger, Maher, and Flattau 1995). ${ }^{12}$ Size is based on enrollment of doctoral students. These assessments covered most of the PhD-granting programs in each discipline, and taken together the assessed programs represent about 90 percent of PhDs granted in a field. For each year, the rankings used in this analysis are the percentile ranks of the average ratings within fields.

Rank and size are assigned to students based on their institution, field, and year of graduate entry. In departments assessed in both 1981 and 1993, the 1981 rank (size) is used for students who entered in 1981 or earlier, the 1993 rank (size) is used for students who entered in 1993 or later, and a weighted average of the two ranks (sizes) is used for students who entered between 1982 and 1992. In departments assessed in 1981 only, the 1981 rank (size) is used for students who entered in 1987 or earlier; students in later entry cohorts are considered to be in programs that were not assessed. In departments assessed in 1993 only, the 1993 rank (size) is used for students who entered in 1987 or later; students in earlier entry cohorts are considered to be in programs that were not assessed.

\footnotetext{
${ }^{12}$ The National Research Council also conducted an assessment in 2005, but I do not use measures from that assessment because the methodology was substantially different from the one used in the 1981 and 1993 assessments (Ostriker et al. 2010).
} 
For the regressions, program rank is parameterized using 10 categories (based on deciles of the distribution within field). Program size is parameterized using three categories (less than 50, 50 to 90, more than 90). An indicator variable is used to identify students in programs that were not assessed.

Job listings by field.

- Anthropology (1975-2005): American Anthropological Association (AAA). Counts of job listings published monthly in Anthropology News (1975-2004) and online in the AAA Jobs Database (2001-2005).

- Classics (1984-2004): American Philological Association (APA). Annual counts of vacancies from APA placement reports for 2001 and 2004.

- Economics (1979-2005): American Economic Association. “New jobs” series (academic plus non-academic) published annually in the May issue of American Economic Review (e.g., Siegfried 2001), based on listings in Job Openings for Economists.

- English (1975-2005): Modern Language Association (MLA). Number of positions listed in the English Edition of the MLA Job Information List; counts from Table 1 of Fall 2004 MLA Newsletter. Data for 2004 through 2006 are taken from Table 1 of the report "Trends in the MLA Job Information List, September 2007.”

- History (1975-2005): American Historical Association (AHA). Job openings advertised in Perspectives; counts based on AHA reports (2004 and 2005) and electronic data provided by AHA (1975-2003).

- Philosophy (1982-2002): American Philosophical Association. Total number of jobs advertised in Jobs for Philosophers; data from pp. 130-131 of American Philosophical Association (2004). 
- Political Science (1983-2005): American Political Science Association (APSA). Data for 1983 through 2003 are based on Brintnall (2005); data for 2004 and 2005 were provided by APSA.

Unemployment rate. National unemployment rate for civilian labor force age 16 and older. Rate for an academic year is computed as the average of monthly seasonally adjusted unemployment rates for August through July. Source: Bureau of Labor Statistics.

State appropriations. State appropriations per full-time-equivalent student are for all U.S. public universities and are expressed in constant (calendar year 2000) dollars. Source: Grapevine database assembled by the Center for the Study of Education Policy at Illinois State University; see Rizzo (2006) for details. Data used in Table 3 are for academic years 19751999.

College expenditures. College expenditures per full-time-equivalent student are for all U.S. public universities and are expressed in constant (calendar year 2000) dollars. Expenditures are current educational and general expenditures, net of sponsored research. Source: IPEDS, U.S. Department of Education; see Rizzo (2006) for details. Data used in Table 3 are for academic years 1975-1999.

Faculty salaries. Faculty salaries are the average salary of full-time instructional faculty on nine-month contracts in degree-granting institutions and are expressed in constant (academic year 2005-06) dollars. Source: National Center for Education Statistics (2007), Table 240. Data used in Table 3 are for selected academic years: 1975, 1978-1982, 1984-1985, 1987, 19891999, and 2001-2005. 